Mariusz Mohyluk

\title{
Leopold Caro o ustawodawstwie radzieckim
}

\begin{abstract}
Summary
Leopold Caro was an outstanding Polish lawyer, working on Uniwersytet Jana Kazimierza in Lvov in the pre-war period. He was analyzing both penal and civil branches of Soviet law in their early period of development. He was very critical about contents of Soviet codes of 1922. His works on Soviet law are original. He can be regarded as one of the pioneers in the research on Soviet law in Poland.
\end{abstract}

W II Rzeczypospolitej Kościół katolicki zajmował wyjątkową pozycję jako instytucja o niepodważalnym autorytecie światopoglądowym i moralnym. Jego niebagatelną rolę w odrodzonym państwie umacniała konstytucja marcowa, przyznająca mu „naczelne stanowisko wśród równouprawnionych wyznań”. Utrwalał ją niewątpliwie konkordat z 1925 r. Z tego też względu, poglądy zarówno duchownych, jak i świeckich środowisk katolickich stanowiły ważny głos w międzywojennych debatach o Rosji Radzieckiej. Spośród polskich przedstawicieli katolickiej nauki społecznej, wypowiadających się w ogóle na temat bolszewizmu, zwracają przede wszystkim uwagę wypowiedzi: ks. Józefa Pastuszki, ks. Antoniego Szymańskiego, ks. Stefana Wyszyńskiego, Leopolda Caro i Ignacego Czumy. Należy także pamiętać o Instytucie Naukowego Badania Komunizmu z siedzibą w Warszawie, na którego czele stał ks. Antoni Kwiatkowski oraz o tzw. "Grupie lubelskiej” działającej w ramach Katolickiego Uniwersytetu Lubelskiego. Badania te miały więc charakter indywidualny i zinstytucjonalizowany ${ }^{1}$.

${ }^{1}$ Zob. M. Kornat, Bolszewizm. Totalitaryzm. Rewolucja. Rosja. Początki sowietologii studiów nad systemami totalitarnymi w Polsce (1918-1939), Kraków 2004 i tam dalsza literatura na ten temat; M. Mohyluk, Prawo radzieckie w nauce i publicystyce prawniczej II Rzeczypospolitej - stan badań i problemy badawcze, „Miscellanea historico-iuridica” 2004, t. 2, s. 67-81. 
Już na początku rozważań chciałbym zaakcentować, że polscy myśliciele katoliccy interesowali się bolszewizmem głównie z perspektywy szeroko rozumianej katolickiej nauki społecznej, sformułowanej w encyklikach Rerum novarum i Quadragesimo Anno. Kanon oceny systemu radzieckiego stworzył również papież Pius XI w encyklice Divini Redemptoris z 1937 r., która ustalała Katolicki program walki z komunizmem, głosząc podstawową tezę, że nie da się pogodzić komunizmu z katolicyzmem. Nie da się pogodzić głównie dlatego, że komunizm opiera się na doktrynie, uznającej za jedyną rzeczywistość materię, a jej „ślepe siły” za „tworzywo dziejów”. W tych realiach trudno o miejsce dla „idei Boga”, nie dostrzega się różnic między „duchem a materią, ciałem a duszą", odmawiając jej „życia wiecznego". Postęp ludzkości gwarantuje jedynie walka klas jako metoda regulowania stosunków społecznych. Zdaniem katolickich krytyków (XIX i XX w.), komunizm głosił idee „fałszywego wyzwolenia” oraz „fałszywej sprawiedliwości, równości i braterstwa w pracy, przepajając naukę i działalność” swych wyznawców „fałszywym mistycyzmem”. Znosił on też „wolność jednostki jako zasadę moralnego działania człowieka, odzierał go $\mathrm{z}$ tego wszystkiego, co stanowi o godności osoby ludzkiej, nie przyznając jej w społeczności kolektywnej praw przyrodzonych" i uznając ją „jedynie za kółko w mechanizmie zbiorowym”. „Błąd antropologiczny” był zasadniczym argumentem dyskwalifikującym doktrynę komunistyczną we wszystkich jej odmianach.

Kultura grecko-rzymska, a później kultura chrześcijańska nieodmiennie zakładała dualizm rzeczywistości: świata zjawiskowego i ponadzjawiskowego albo świata ducha. Człowiek wrasta w oba światy i oba w sobie jednoczy, rozwijając w szczupłych granicach jestestwa fizycznego życie duchowe, życie myśli i woli, życie uczuć i ideałów, które wykracza poza granice zjawiskowości. Z ciążenia ku światu transcendentnemu, któremu przysługuje obiektywizm, wyrasta jego religia i moralność, prawo i obyczaje. Człowiek wrasta w sferę ideałów duchowych i w nich upatruje sens życia. Idea duchowości człowieka wywarła głęboki wpływ na rozwój kultury europejskiej, bowiem w jej atmosferze ideowej człowiek coraz bardziej wyodrębniał się od przyrody, uświadamiał sobie swą wyższość, swą autonomię i swe uprawnienia władcze $\mathrm{w}$ stosunku do świata zjawiskowego. Tymczasem materializm komunistyczny przerwał dotychczasową linię rozwojową i spowodował pomniejszenie, zdeklasowanie i depersonifikację człowieka. W komunizmie człowiek zajmuje stanowisko podrzędne, bo nowymi pojęciami metafizycznymi stały się: produkcja, kapitał, praca, towar, pieniądz, wartość. Pojęcia te miały teraz określać istotę człowieczeństwa. Człowiek stracił status jednego z elementów stworzenia i tym samym miejsce w planie stwórczym Boga. Determinizm sił ekonomicznych przytłaczał człowieka, odbierał mu jego twórczość, autonomię i samodzielność, czynił wypadkową sił przyrody, małym kółkiem, 
w olbrzymiej maszynerii świata, poddanym prawom fizycznym, działającym z bezwzględną koniecznością ${ }^{2}$.

Z tak krytycznie pojmowaną przez Kościół katolicki doktryną komunizmu w pełni utożsamiał się Leopold Caro - wybitny ekonomista, myśliciel polityczny i działacz społeczny. Urodził się 27 V 1864 r. we Lwowie. Studiował ekonomię oraz prawo na uniwersytecie w Lipsku. Po powrocie do rodzinnego Lwowa studiował również filozofię i obronił doktorat $\mathrm{z}$ zakresu prawa. Przez wiele lat był wykładowcą ekonomii na Uniwersytecie Jana Kazimierza, a w latach 1924-1935 prowadził wykłady z zakresu ekonomii oraz nauk społecznych na Politechnice Lwowskiej. Był aktywnym członkiem Polskiego Towarzystwa Ekonomicznego. Swoje prace publikował $\mathrm{w}$ wielu czasopismach, współpracował $\mathrm{z}$ „Czasopismem Prawniczym i Ekonomicznym”, „Przeglądem Powszechnym” oraz „Ateneum Kapłańskim”. W 1932 r. został powołany na stanowisko wiceprzewodniczącego Rady Społecznej przy Prymasie Polski. L. Caro uznawany jest za prekursora solidaryzmu chrześcijańskiego na ziemiach polskich. Wielki wpływ wywarły na niego koncepcje K. Gide, T. Carlyle, L. Bourgeois i J. Ruskina, faktyczną podstawą jego systemu było jednak przede wszystkim nauczanie społeczne Kościoła. Zmarł 8 II 1939 r. we Lwowie ${ }^{3}$.

Leopold Caro był uważany za jednego z najlepszych w II RP znawców bolszewizmu. Krytykował kolektywizm, który legł u podstaw bolszewickiej koncepcji państwa. Odrzucał bolszewizm ze względu na teorię walki klas. Odpowiedzią na nią miała być „etyka współdziałania”, którą uważał za podstawę i gwarancję solidaryzmu społecznego. W artykule Materializm dziejowy jako jedna z podstaw marksizmu ${ }^{4} \mathrm{w}$ sposób naukowy rozprawił się z teorią materializmu dziejowego, wykazując tkwiące w niej sprzeczności i luki. Obalił tezę, iż wyłącznie stosunki produkcyjne, wraz ze stosunkami obrotu i zamiany, stanowią podstawę i źródło wszystkich wypadków dziejowych. Zwrócił uwagę, że teoria ta nie wyjaśnia kwestii, dlaczego, mimo identycznych warunków gospodarki kapitalistycznej w różnych państwach, uwydatniają się w nich bardzo znaczne różnice narodowe i kulturalne oraz odmienne losy dziejowe. Jego zdaniem, fałszywym założeniem jest traktowanie idei (choć mogą być one bezpośrednimi przyczynami tych założeń) tylko jako refleksji każdorazowego ustroju gospodarczego danego społeczeństwa w pewnej epoce, z pominięciem jakichkolwiek dążeń ludzkości do większej sprawiedliwości ustroju społecznego. Walki klasowe, jako wynik zjawisk

${ }^{2}$ B. Szlachta, Krytyka komunizmu w polskiej myśli katolickiej i konserwatywnej, www.omp.org.pl. Tekst ten opublikowano także w wydanej przez Ośrodek Myśli Politycznej książce Antykomunizm po komunizmie, Kraków 2000.

${ }^{3}$ M. Marszał, Amica Italia. Polscy prawnicy wobec włoskiego faszyzmu 1922-1939. Wybór pism, Kraków 2004, s. 230; zob. też www.omp.org.pl.

${ }^{4}$ „Przegląd Współczesny” 1923, t. 6, nr 16, s. 178-182 i 193-197. 
ekonomicznych, nie mogą być jedynymi bodźcami, które torują drogę etapom historii. Przy takim rozumieniu historii nie ma miejsca dla wybitnych jednostek i niewiele go zostaje dla wolności woli. Uczucia religijne, etyka, twórczość artystyczna i naukowa nie mogą wynikać wyłącznie ze stosunków gospodarczych. „Nasza świadomość mówi nam - pisze L. Caro - że płyną one ze źródeł zgoła odmiennych. Odpowiada wprawdzie Engels, że świadomość indywidualna jest iluzją i pochodzi z błędnych zgoła wyobrażeń, a prawdziwą jest tylko świadomość kolektywna. A jednak indywidualna świadomość jest jedynym źródłem, za pośrednictwem którego dowiadujemy się tak o czynnikach gospodarczych jak i o innych. Innego źródła nie ma i sam materializm dziejowy, stanowiący rzekomo pewną, bo »naukową « zdobycz marksizmu”. Słusznie zauważa L. Caro, że teoria walki klas pomija kwestie wojen między poszczególnymi narodami oraz wojen na tle różnic religijnych, już niezależnie od tego, kto je wywołał, jaka była ich praprzyczyna. Tłumaczone przez marksistów powstanie i upowszechnienie chrześcijaństwa walką obudzonego proletariatu nie wyjaśnia jego permanentności.

Dzieje ludzkości stają się u Marksa ekonomiczną historią nadwartości. Jest to fałsz, a przynajmniej niewielka część prawdy - jak tego dowiódł, posługując się naukową argumentacją, L. Caro. Fałsz ten, myśl i paradoksalnie idea, są niebezpieczne i groźne, bo już realizowane w karykaturalnej formie w państwie radzieckim ${ }^{5}$.

${ }^{5} \mathrm{~W}$ innym tekście, zatytułowanym Solidaryzm. Jego zasady, dzieje i zastosowania, tenże autor uzupełnił przywołany wywód ogólniejszymi uwagami: „Liberalizm ekonomiczny nie zadaje sobie pytania, jak należy urządzić stosunki gospodarcze i społeczne, czyli jaki ma być porządek społeczny, aby wszyscy ludzie czuli się naprawdę wolnymi. Dla niego jedynym godnym wysiłku celem jest jak najszersza i niczym nie skrępowana swoboda, rozumie się dla tych tylko jednostek, które swobody tej używać, a w danym razie nadużywać są w stanie; reszta poprzestać może i winna na teoretycznym jeno do niej uprawnieniu. Zupełne uruchomienie wszelkiej własności, wolność lichwy i giełdy, nieograniczona podzielność ziemi i nieograniczona wolność jej obdłużania, stanowiły smutne zdobycze tej szkoły, ku której mimo owych doświadczeń, naprawianych potem w blisko półwiekowym trudzie ustawodawczym, zwrócili się po wojnie światowej na nowo zniecierpliwieni nieudolną gospodarką przymusową państw wojujących, spodziewając się po powrocie haseł liberalnych zmiany na lepsze. Powrót ten jednak pobudził groźny opór socjalizmu, który doszedłszy do niebywałej przedtem potęgi, na swój sposób etykę wyłączył poza nawias. Urodzony niewątpliwie z pobudek etycznych, wyszydzony za to przez Marksa mianem utopijnego, socjalizm w ujęciu Marksa stworzył teoretyczną podstawę swych poglądów filozoficznych i gospodarczych w teorii materializmu dziejowego, a jako cel wytknął sobie dyktaturę proletariatu. Hasło to, podobnie jak liberalizm, pamięta tylko o interesie własnej warstwy. Nie demokracja i równouprawnienie, ale panowanie jednej warstwy, dotychczas upośledzonej i pozbawionej praw, to jego istota. Żądanie dyktatury proletariatu, a więc oddania władzy pewnym ludziom tylko dlatego, że do proletariatu należą, jest objawem powszechnego kultu niekompetencji, cechującego nasze czasy, ale poza tym powierzenie rządów w państwie najmniej do tego przygotowanym, wydaje je faktycznie w ręce niepowołanych przywódców z innych warstw, co zmniejsza nielogiczność pomysłu, ale narzuca społeczeństwu na kierowników osobistości pod względem etycznym najmniej pożądane. Ekonomiści liberalni i marksiści rozumieją wybornie, że potrzeba im pewnego punktu oparcia. Upatrują go w „prawach ekonomicznych”. 
Leopold Caro najwięcej miejsca Rosji Radzieckiej poświęcił w artykule Idee przewodnie ustawodawstwa sowieckiego ${ }^{6}$. Już w pierwszych zdaniach stwierdza, że ustawodawstwo radzieckie służy w całości i niepodzielnie interesom klasy panującej, tj. dyktaturze proletariatu ${ }^{7}$. Faktycznie jednak ustawy te stwarzają dla szczupłej garstki elity władczej warunki dyktatury nad proletariatem.

W opinii L. Caro najwyższym i jedynym celem radzieckiego prawodawstwa jest wcielenie w życie idei rewolucyjno-komunistycznych i utrzymanie się przy władzy. Był to trafny wniosek, zresztą zgodny z programem W. I. Lenina, nakreślonym w książce Państwo i rewolucja w 1917 r. ${ }^{8}$ W pracy tej „wódz rewolucji” zbudował teorię roli państwa w okresie przejściowym między kapitalizmem i komunizmem, który mógł być długotrwały. Anarchia nie mogła sprzyjać w żadnym wypadku skutecznej i sprawnej organizacji władzy rewolucyjnej. Dyktatura proletariatu, tzn. dyktatura partii komunistycznej, miała oznaczać władzę silniejszą i bardziej despotyczną niż w państwach burżuazyjnych. W okresie przejściowym, gdy społeczeństwo nie było jeszcze „komunistyczne” (bezklasowe), państwo $\mathrm{z}$ silną władzą centralną jest niezbędne dla dyktatorskich rządów proletariatu nad

Z chwilą, gdy to oparcie okazuje się złudnym, ich konkluzje zawisają w powietrzu. Twierdzą przy tym, że wniknięcie w kwestię tego, co być powinno, nie należy do ekonomiki społecznej i że nauka ta, podobnie jak nauki przyrodnicze, rejestrować ma jedynie, co jest, badać przyczyny i skutki zjawisk. Marks w szczególności nie uznaje sądów wartościujących, tj. właśnie oceny faktów gospodarczych ze stanowiska tego, co być powinno. Wprowadzony w błąd przez dialektykę Heglowską, poczytuje wszelką rzeczywistość za logicznie usprawiedliwioną. A jednak w krytyce ustroju kapitalistycznego ten sam Marks najostrzejszymi słowami piętnował wyzysk przedsiębiorców angielskich, wydając tym samym sąd wartościujący ze stanowiska etyki, którą wszak usuwał od wszelkiego wpływu w dziedzinie stosunków gospodarczych. [Tymczasem] cała polityka ekonomiczna, tj. część praktyczna ekonomiki społecznej polega na badaniu dobrych czy złych skutków tego lub owego urządzenia lub ustawy, opiera więc swe wnioski nie tylko na poznaniu, ale i na działaniu, oceniając je tak wedle używanych środków, jak i wedle osiągniętych rezultatów. Ale i teoretyczna ekonomika nie może się obejść bez teleologii, tj. sądów wartościujących. (...) Kwestia celu w gospodarstwie nie może więc być pominięta. Celem tym zaś nie może być nic innego, jak tylko dobro publiczne. Wobec tego za zadania gospodarstwa społecznego uznać należy pokrywanie potrzeb społeczeństwa zgodnie $\mathrm{z}$ dobrem publicznym. Dobro to atoli nie może być osiągnięte w drodze wyzysku jednych przez drugich, wszelka bowiem niesprawiedliwość byłaby sprzeczną z publicznym dobrem. Dla życia gospodarczego istnieją tedy tak samo obowiązki moralne, jak w życiu indywidualnym. Każdy ustrój społeczny musi się dostosować do wymogów etyki; jeżeli pozostaje z nią w sprzeczności, ulegnie niewątpliwie przekształceniu i to bądź w drodze ewolucji bądź rewolucji. Wykluczenie etyki przez Ricarda i Marksa rozpętało walkę klasową, a ideą pokoju i solidarności społecznej doprowadziło państwo do bankructwa. Ani państwo pasożytów giełdowych, dla których egoizm, spryt i wolna konkurencja są jednymi prawami, ani dyktatura proletariatu nie mają warunków trwałej egzystencji. Nie tylko silni, ale i słabi maja prawo do życia, nie tylko przebiegli, ale i prostoduszni, nie tylko ciemni, ale i oświeceni. Zwalczanie niedogodnego dla ludzi u steru będących światopoglądu w drodze materialnego rujnowania lub więzienia i zabijania inaczej myślących jest stanem rzeczy, godnym dżungli, ale nie ludzi gromadnie żyjących i pragnących tworzyć społeczeństwo". Lwów 1931, s. 99-102.

${ }^{6}{ }_{7}$ Ruch Prawniczy, Ekonomiczny i Socjologiczny” 1929, R. IX, s. 205-223.

${ }^{7}$ Ibidem, s. 206.

${ }^{8}$ www.marxists.org/polski/lenin/. 
burżuazją w celu jej zniszczenia. W. I. Lenin wprost wyrażał pogląd, że pierwsze etapy realizacji komunizmu nie mogą być wolnością i równością. Dyktatura ta była więc celowo nacechowana przemocą i nierównością. Nie powinien dziwić zatem paradoks bolszewizmu, polegający na tym, iż z jednej strony przywódcy radzieccy głosili hasła obumierania państwa, a z drugiej rozbudowywali aparat przemocy.

Konsekwencją tak rozumianej roli dyktatury proletariatu w okresie przejściowym był - jak zaznaczył L. Caro - brak podziału władz. Władza ustawodawcza zlewała się z wykonawczą, wykonawcza z ustawodawczą. Władze sądowe z kolei, głównie z potrzeby chwili, stawały się niejednokrotnie źródłem rewolucyjnego prawa. Zdaniem bolszewików, zasada podziału władz była zawsze fikcją, albowiem i tak w całości spoczywała ona w rękach klas panujących. W obrębie władzy wykonawczej i sądowniczej - podkreślał L. Caro - bolszewicy uznawali praworządność tylko „do tej granicy, w której popadłaby ona w sprzeczność $\mathrm{z}$ żądaniem sumienia rewolucyjnego i klasowymi interesami proletariatu"' ${ }^{\prime \prime} \mathrm{Wy}-$ łącznie rozstrzygające były tu względy celowości i należało pod nimi rozumieć interesy klasowe proletariatu. Rewolucyjnym sądom polecono, aby kierowały się „W swoich orzeczeniach i wyrokach ustawami obalonych rządów tylko o tyle, o ile takowe nie zostały obalone przez rewolucję i nie sprzeciwiają się rewolucyjnemu sumieniu i rewolucyjnej świadomości” ${ }^{10}$. Pojęcia: „rewolucyjne” („socjalistyczne”), sumienie i świadomość prawna stały się więc „kluczową klauzulą generalną nowego porządku prawnego" ${ }^{11}$. Terminy te miały służyć - począwszy od Dekretu o sadzie nr 1 - szybkiej deprecjacji i likwidacji przedrewolucyjnego ustawodawstwa.

Dotychczasowy system prawny zaczęto traktować posiłkowo a nadrzędną doktryną porządku państwowego stała się doktryna „praworządności rewolucyjnej”, u której źródeł legły właśnie wymogi rewolucyjnego sumienia i klasowe interesy proletariatu. W związku z tym, kształtujące się prawo zmieniało całko-

${ }^{9}$ L. Caro, Idee przewodnie..., s. 217.

${ }^{10}$ Punkt 5) Dekretu o sądzie $n r 1 \mathrm{z} 24$ listopada 1917 r. stanowi: „Sądy lokalne rozpatrują sprawy w imieniu Republiki Rosyjskiej i kierują się w swoich orzeczeniach i wyrokach ustawami obalonych rządów tylko o tyle, o ile takowe nie zostały obalone przez rewolucję i nie sprzeciwiają się rewolucyjnemu sumieniu i rewolucyjnej świadomości prawnej”. W art. 36 Dekretu o sadzie $n r 2$ z 15 lutego 1918 r. (w części jedenastej O obowiazujacych ustawach) czytamy: „W sprawach cywilnych karnych sąd kieruje się ustawami cywilnymi i karnymi dotychczas obowiązującymi tylko o tyle, o ile takowe nie zostały uchylone przez dekrety Centralnego Komitetu Wykonawczego i Rady Komisarzy Ludowych oraz nie są sprzeczne z socjalistyczną świadomością prawną (...)”. W art. 3 Dekretu o sądzie nr 3 z 13 lipca 1918 roku natomiast umożliwiono „lokalnym sądom ludowym orzekanie kar do 5-ciu lat pozbawienia wolności, w oparciu o dekrety Rządu Robotniczo-Chłopskiego i socjalistyczne sumienie”. Zob. A. Bosiacki, Utopia władza prawo. Doktryna i koncepcje prawne „bolszewickiej” Rosji 1917-1921, Warszawa 1999, s. 341-353.

${ }^{11}$ Ibidem, s. 153. 
wicie swoją treść klasową, gdyż miało bronić wyłącznie zdobyczy państwa robotników i chłopów przed zamachami ze strony jego przeciwników. Ten klasowy charakter prawa wywodzono z marksistowskiego założenia, że w ogóle pojawia się ono dopiero wówczas, gdy powstaje państwo. „Historia wykazuje - pisał Lenin - że państwo jako aparat przymusu, powstawało tylko tam i wtedy, gdzie i kiedy powstawał podział społeczeństwa na klasy - tzn. podział na takie grupy ludzi, z których jedne mogą stale przywłaszczać sobie prace innych, gdzie jeden wyzyskuje drugiego"12. Prawo istniejące tylko w państwie chroniło interesy klasy panującej, a więc „wyzyskiwaczy przed zamachami ze strony wyzyskiwanych”.

Od 1917 r. władzę skutecznie przejmowali bolszewicy, którzy na gruzach carskiego gmachu budowali państwo nowego typu - robotniczo-chłopskie, gdzie nadrzędnym stawało się prawo nowego typu. Prawo to powstawało spontanicznie, ad hoc a jego źródło wypływało z rewolucyjnego sumienia i świadomości. „Państwo sowieckie - pisał Konstanty Grzybowski - nie jest państwem prawnym. Podstawą działalności organów państwowych oraz praw i obowiązków obywateli nie są obiektywne normy prawne, uprzednio opublikowane i mogące ulec zmianie tylko w pewien z góry określony sposób. Naczelną zasadą porządku państwowego jest pewna doktryna polityczno-socjalna, doktryna komunistyczna, a normy prawa pisanego stanowią jedynie wytyczne"13. Ignacy Czuma słusznie zauważył, że prawo w Związku Radzieckim ,jest systemem norm socjalnych, wytwarzanych i utrzymywanych przez określoną siłę społeczną. Prawo tworzą ci, którzy mają siłę, norm tych broni w dalszej konsekwencji ta sama siła, która powstanie normy inspiruje, która normy dla siebie urządza. Tak wygląda teza sowiecka o prawie. Ponieważ zaś w sowietach siła ta formalnie należy do klasy proletariatu, zatem łatwo nam określić sobie kierunek treściowy wytwarzanych norm. To jest całe usprawiedliwienie prawa"14.

W kolejnych rozważaniach na temat ustawodawstwa radzieckiego L. Caro przeanalizował treść art. 1 kodeksu cywilnego z listopada $1922 \mathrm{r} .{ }^{15}$ Nie zgodził się on $\mathrm{z}$ opinią, iż artykuł ten opiera się na ideach słynnego francuskiego prawnika L. Duguita, głoszącego pogląd o funkcji społecznej prawa. Zadaniem prawa według L. Duguita nie jest ochrona praw indywidualnych, ale umożliwienie, by w interesie państwa wszyscy mogli wobec niego wypełniać swoje społeczne obowiązki ${ }^{16}$. Własność w świetle poglądów L. Duguita łączy się ściśle i stale

${ }^{12}$ W. I. Lenin, O państwie, Warszawa 1950, s. 11.

${ }^{13}$ Antykomunizm polski. Tradycje intelektualne, B. Szlachta (red.), Kraków 2000, s. 145-146.

${ }^{14}$ Ibidem, s. 150.

${ }^{15}$ „Uprawnienia prywatne doznają ochrony prawnej z wyjątkiem tych wypadków, w których urzeczywistnione są wbrew swemu społeczno-gospodarczemu przeznaczeniu”.

${ }^{16}$ H. Olszewski, M. Zmierczak, Historia doktryn politycznych i prawnych, Poznań 1994, s. 414-415 . 
$\mathrm{z}$ obowiązkiem utrzymania jej w interesie dobra publicznego. Interes publiczny (społeczny), tak mocno zaakcentowany w niniejszym artykule jako ostateczne źródło prawa, był jednak, zdaniem L. Caro, konstrukcją niezbyt jasną, bo „na czym ten interes polega, to pozostaje nadal tajemnicą, a wszelkiej samowoli zostają otwarte wrota" ${ }^{17}$. Słusznie więc dalej zauważył, że cele społeczne w państwie radzieckim więcej niż gdziekolwiek indziej „są ciągle jeszcze w stanie płynnym”. $\mathrm{W}$ okresie komunizmu wojennego cele społeczne były zupełnie inne niż np. w okresie NEP-u. W tych warunkach trudno o bezpieczeństwo prawne, gdyż np. wszelkie umowy, koncesje i prawa przyznane przedsiębiorcom zagranicznym mogły być zgodnie z tą normą w każdej chwili uchylone.

L. Caro bardzo krytycznie, choć dość pobieżnie, odniósł się do radzieckiego ustawodawstwa karnego. Negatywnie ocenił treść art. 23 kodeksu karnego z 1922 roku $^{18}$. W artykule tym w brzmieniu: „Kodeks karny stosuje się do wszystkich czynów, które przed wprowadzeniem tegoż w życie nie były jeszcze przez sąd rozpatrywane" została sformułowana zasada co do obowiązywania ustawy pod względem czasu. Zdaniem L. Caro, usankcjonowano tu zasadę lex retro agit. Taka regulacja ułatwiała prowadzenie procesów przeciwko osobom dawnego systemu, oskarżonych o działania kontrrewolucyjne. Potwierdzał ją art. $67 \mathrm{KKR}$, który stanowił o „czynnych działaniach lub czynnej walce, podjętych przeciwko klasie robotniczej i ruchowi rewolucyjnemu w czasie ustroju carskiego na odpowiedzialnych lub specjalnych poufnych (wywiad) stanowiskach", a decyzje o ewentualnym ich przedawnianiu pozostawiono do uznania sądu (art. 33 KKR).

W dalszych rozważaniach na temat radzieckiego kodeksu karnego L. Caro skoncentrował się na pojęciu przestępstwa ${ }^{19}$. Kodeks z roku 1922 (jak i późniejszy z roku 1927) podawał rodzajowe określenie przestępstwa. Art. 6 KKR stanowił: „Za przestępstwo poczytuje się wszelkie społecznie niebezpieczne działanie lub zaniechanie, zagrażające podstawom ustroju sowieckiego, oraz porządkowi prawnemu, który przez Władzę Robotniczo-Włościańską ustanowiony został na przejściowy okres czasu, prowadzący do ustroju komunistycznego". To szerokie określenie dopuszczało interpretację prowadzącą do tego, iż właściwie każde działanie lub zaniechanie obywatela mogło być naruszeniem porządku prawnego. Uzupełnieniem cytowanego artykułu był niewątpliwie art. $10^{20}$. Wprowadzał

${ }^{17}$ L. Caro, Idee przewodnie..., s. 220.

${ }^{18}$ Ibidem.

${ }^{19}$ Ibidem, s. 220-221.

${ }^{20}$ Art. 10 KKR: „W razie braku w Kodeksie Karnym bezpośrednich wskazówek co do poszczególnych rodzajów przestępstw, wymierza się kary względnie środki ochrony socjalnej zgodnie z tymi artykułami Kodeksu karnego, które przewidują przestępstwa najbardziej podobne co do doniosłości i rodzaju, z zachowaniem przepisów ogólnej części niniejszego Kodeksu”. 
on zasadę analogii, łamiąc zasadę nullum crimen, nulla poena sine lege. W świetle tych przepisów każdy obywatel był potencjalnym kandydatem na przestępcę. W identyczny sposób definiowano przestępstwo w Przewodnich zasadach prawa karnego RFSRR z roku 1919 (w art. 5 i 6). Definicje te akcentowały klasową istotę przestępstwa, podkreślając jego niebezpieczeństwo społeczne, zachowując jednocześnie kryterium bezprawności. Analizując zatem radzieckie definicje przestępstwa, można wyodrębnić następujące jego podstawowe cechy:

- przestępstwo jest zjawiskiem historycznie konkretnym i zmiennym;

- przestępstwo jest zamachem na panujące stosunki społeczne (tu ustanowione przez Władzę Robotniczo-Włościańską);

- przestępstwo jest czynem społecznie niebezpiecznym (zagrażającym w pierwszej kolejności podstawom ustroju sowieckiego oraz określonemu porządkowi prawnemu) ${ }^{21}$.

Zdaniem L. Caro, wszelka analogia w prawie karnym powinna być uchylona $^{22}$. Inny wybitny polski prawnik, karnista J. Makarewicz, wypowiadając się na temat tegoż kodeksu, zarzucał tak pojmowanym przestępstwom brak znajomości techniki ustawodawczej. Jego zdaniem, z jednej strony powinno unikać się wciągania do ustaw tego, co należy do dziedziny nauk prawnych. $Z$ drugiej strony jednak przypuszczał, iż była to pozorna ignorancja, kryjąca za sobą możliwość szerokiego, praktycznie nieograniczonego, stosowania kar. W opinii J. Makarewicza, dopuszczenie zasady analogii w połączeniu z klauzulą socjalistycznego poczucia prawnego (art. $9 \mathrm{KKR}$ ) „wskazują, że mamy do czynienia z kodeksem karnym o charakterze politycznym, rewolucyjnym, że uwaga ustawodawcy skierowana jest na tępienie ludzi o przeciwnym, niż panujący, poglądzie społecznym i prawnym" 23 . Wprowadzenie zasady analogii w radzieckim prawie karnym wynikało w naturalny sposób z prawidłowości rozwoju rewolucyjnego wymiaru sprawiedliwości i uwarunkowane było brakiem dostatecznego doświadczenia ustawodawczego bolszewików oraz zmiennością sytuacji społeczno-politycznej. Praktyka stosowania analogii miała przyczynić się do szybkiej reakcji sądów na nowe przestępstwa, nie przewidziane w kodeksie, bez czekania na wydanie kolejnych ustaw ${ }^{24}$. J. Makarewicz, powołując się na oficjalny komentarz do KKR, konkludował że tego rodzaju stanowisko „odpowiada wszelkiej tyranii, wykonywanej w imię jakichkolwiek interesów, jest zupełnym zaprzeczeniem wolności i spokoju obywatela”25. Władysław Wolter twierdził, iż „uchylenie zakazu analo-

${ }^{21}$ A. A. Gercenzon, Prawo karne, część ogólna, Warszawa 1952, s. 296.

${ }^{22}$ L. Caro, Idee przewodnie, op. cit., s. 221.

${ }^{23} \mathrm{~J}$. Makarewicz, Kodeks karny republik sowieckich, Warszawa 1926, s. 12.

${ }^{24}$ Ugalownoje prawo. Obszczaja czasc, A. A. Gercenzon, B. S. Oszerowicz, A. A. Piątkowski (red.), Moskwa 1939, s. 159-161.

${ }^{25}$ J. Makarewicz, Kodeks karny, op. cit., s. 13-14. 
gii przestaje tu być jakimś wyłomem, jakimś wątpliwym rozszerzeniem a staje się wprost integralną częścią systemu nowego, jak cały ustrój sowiecki, czymś zgoła obcym innym ustawodawstwom karnym"26.

\section{Podsumowanie}

Analizując wypowiedzi L. Caro o radzieckim ustawodawstwie, można skonstatować, że odnosił się on do niego zdecydowanie krytycznie. Świadczą o tym jego uwagi do radzieckiego kodeksu karnego i cywilnego z $1922 \mathrm{r}$.

Stricte jurydyczne badania lwowskiego uczonego były oryginalnymi opracowaniami tego typu na gruncie polskich nauk prawnych. Można go uznać za jednego z prekursorów studiów nad radzieckim prawem. Uwagi do kodeksu karnego i cywilnego z 1922 r. utrzymane były w granicach naukowego przedstawienia jego zasad i poszczególnych przepisów.

${ }^{26} \mathrm{~W}$. Wolter, Czy uchylić zakaz analogii w prawie karnym?, „Czasopismo Prawnicze i Ekonomiczne” 1936, R. XXX, s. 49-50. 